\title{
Joanna Trzęsiok
}

University of Economics in Katowice

e-mail: joanna.trzesiok@ue.katowice.pl

ORCID: 0000-0001-7937-7190

\section{Sylwia Slupik}

University of Economics in Katowice

e-mail: sylwia.slupik@ue.katowice.pl

ORCID: 0000-0001-5141-6178

\section{THE IDENTIFICATION AND ANALYSIS \\ OF THE FACTORS AFFECTING ENERGY \\ CONSUMER BEHAVIOUR}

\section{IDENTYFIKACJA I ANALIZA CZYNNIKÓW \\ WPEYWAJĄCYCH NA ZACHOWANIE KONSUMENTÓW ENERGII}

DOI: $10.15611 / \mathrm{pn} .2019 .6 .09$

JEL Classification: Q490, C380

Summary: The article aims to identify energy consumer behaviour, particularly in the area of energy saving. Trends in contemporary consumption, including energy consumption, reveal that an increasing number of consumers make purchase decisions in a conscious and rational manner. This is caused by the globalization and integration of markets, evolving lifestyles and social trends. Modern energy consumers are also concerned with their footprint on the natural environment. Using data, gathered in the survey, the authors conducted principal component analysis, selecting 12 new variables that represent the basic types of energy consumer behaviour focused around rational and sustainable energy consumption. The study also examined the factors that significantly influenced consumer attitudes and behaviour. The results showed that generally energy saving actions were not related to the income factor. Education, employment status and age also had a very limited influence on energy consumer attitudes.

Keywords: energy consumption, energy consumer behaviour, principal component analysis.

Streszczenie: Celem artykułu jest identyfikacja zachowań konsumentów energii, przede wszystkim pod względem ich działań dotyczących oszczędzania energii. Trendy współczesnej konsumpcji, w tym również dotyczącej energii, pokazują, że coraz więcej osób świadomie i racjonalnie podejmuje decyzje dotyczące zakupów. Wpływ na to mają zjawiska globalizacji i integracji rynków, zmiany stylu życia czy pewne trendy społeczne. Konsumenci energii coraz częściej kierują się też dobrem środowiska naturalnego. Wykorzystując dane będące 
wynikiem badania ankietowego, w artykule przeprowadzono analizę głównych składowych, wyłaniając 12 nowych zmiennych reprezentujących podstawowe typy zachowań użytkowników skoncentrowanych wokół racjonalnej i zrównoważonej konsumpcji energii. Zbadano też, jakie cechy istotnie wpływają na te postawy i zachowania. Okazało się, że działania mające na celu oszczędność energii nie są na ogół powiązane z czynnikiem dochodowym. Wykształcenie, status zawodowy czy wiek w niewielkim stopniu kształtują również postawy konsumentów energii.

Słowa kluczowe: konsumpcja energii, zachowanie konsumentów energii, analiza głównych składowych.

\section{Introduction}

In today's world of global warming, ozone depletion and environmental pollution, every energy saving solution is worth its weight in gold. Policies encouraging energy consumers to reduce consumption should be implemented and pursued by countries in which both individual and industrial consumption leads to the degradation of the natural environment. Unfortunately, this is not a common practice, for example Poland's economy primarily relies on the use of coal as the main source of energy. Therefore it is both worthwhile and important to recognize the role of the initiatives undertaken by NGOs, science institutes, private businesses, and EU programmes aimed at changing energy consumer behaviour so that they become more rational.

The research project eco-bot ${ }^{1}$, financed under the EU's Horizon 2020, is one of such initiatives, while the international project consortium ${ }^{2}$ includes the University of Economics in Katowice and the authors of the article are members of its research team. The eco-bot project aims to change energy consumer behaviour towards energy efficiency and pro-ecological actions. Its goal is to develop a virtual, personalized assistant that will provide information on energy consumption on a regular basis and inform the consumer what actions to take to reduce consumption and save energy. The team from the University of Economics in Katowice is responsible for the development of a statistical model of energy consumer behaviour.

Based on the results already achieved in the eco-bot project, in particular information from the survey completed by selected customers of the energy suppliers that are the partners in the project, the article attempted to determine the basic types of energy consumer behaviour and factors that affect it. Accordingly, the aim of the article was to identify consumer attitudes, which turned out to be focused primarily on rational energy consumption and its saving. In addition, analysis was performed

${ }^{1}$ This project is co-funded by the European Commission under the "H2020-EU.3.3.1. - Reducing energy consumption and carbon footprint by smart and sustainable use" program topic, according to the Grant agreement No. 767625". More information on the project Personalised ICT-tools for the Active Engagement of Consumers Towards Sustainable Energy: http://eco-bot.eu.

${ }^{2} \mathrm{http}: / /$ eco-bot.eu/partners. 
to determine to what extent demographic and economic factors (i.e. age, education, employment status, and income) affected the attitudes and behaviour of the energy consumers identified in the survey. The study applied multivariate statistical methods, i.e. principal component analysis and the Kruskal-Wallis test, while the calculations were performed using SPSS statistical software.

\section{Contemporary consumption trends}

The consumer is a dynamic individual whose behaviour is constantly evolving, while contemporary consumption is no longer treated as purchasing, possessing or using, because most consumers see it as a way to determine their own "self" and their position in the consumer environment (Woś, Rochacka, and Kasperek-Hoppe, 2004, p. 102). Under changing market conditions, globalization and convergence of cultures, as well as with advancing information and telecommunications technologies, consumer behaviour is evolving towards new trends perceived as changes in preferences and consumption patterns. Their diversity and intensity across countries depend primarily on the level of economic development and consumer affluence, but consumer awareness in the area of environmental protection and its impact on people's life now and in the future also plays an important role.

The main consumption trends observed nowadays comprise (Sobczyk, 2014, pp. 93-102):

1. The changing consumption structure, which is closely related to the strength of the economy and the economic situation as well as to the level of income and quality of life. The increasing standard of living and the satisfaction of basic needs cause changes in the breakdown of expenditure on particular types of goods purchased by consumers; they spend more on superior goods and less on food. The trend also involves the so-called servicization of consumption, i.e. an increase in the share of services in the consumption structure and the growing consumption of intangible goods.

2. Consumer hedonism. The global market manipulates the needs of consumers and imposes a consumer lifestyle on them. As a result we can observe the emergence of consumerism labelled as excessive and unsustainable consumption, involving the irrational purchase of products and services unjustified by one's real needs. Such consumption does not take into account social, ecological and individual costs, which directly leads to waste. Consumers are convinced that the growing level of the satisfaction of material needs influences their self-fulfilment and allows them to achieve a higher position and status in the social hierarchy. Purchase decisions made under time pressure, in an impulsive, imprudent and often routine (habitual) manner, also contribute to the growth in such consumerism. Additionally, excessive consumption relates to postmodern consumption, i.e. volatile, fast and ostentatious consumption (Bednarz, 2017, p. 10). Consumer hedonism, defined as finding pleasure in and enjoying the possession of material goods, is becoming increasingly prevalent. These psychosocial patterns in consumer behaviour are founded on 
imitation, snobbery and excessive consumption which has become a way to boost one's mood, reward oneself or combat boredom.

3. Consumption ecologization, which is the result of growing ecological awareness of society and manifests itself mainly in the consumption of organic food and pro-ecological behaviour in households. The ecological consumer is interested in waste sorting, the use of biodegradable bags, and reduced water and energy consumption. This behaviour combines ecological motivation with household savings and is becoming increasingly common as a result of information and educational campaigns. Not only do consumers use goods rationally and manage them wisely, but they also purchase products generating a small amount of waste and manufactured in agreement with the needs of the environment, and think more about what and how much they buy.

4. Responsible and sustainable consumption, defined by the consumer's pro-ecological values and attitudes that build environmental awareness and lead to ecologically and socially responsible purchase decisions. Its manifestation is the economical and rational consumption of consumer goods and natural resources, as well as a conscious and intentional reduction in the consumption of products requiring rare, non-renewable resources and generating significant amounts of waste.

5. Deconsumption, which often translates into joint consumption known as collaborative consumption or a sharing economy. Consumers consciously and intentionally limit the amount of goods that they consume or share, rent or exchange with other consumers. The idea rests on the assumption that we want to save on the purchase of new products, use them more rationally, be more flexible about satisfying the needs that only occur on an occasional basis. The trend is mainly attributable to the transition towards a more healthy and frugal lifestyle; other changes that contribute to deconsumption are servicization and dematerialization of consumption, increasing quality aspirations, the lower rank of consumption in the hierarchy of life values, and the desire to protect natural resources.

6. Smart shopping, or intelligent shopping that prevails in times of economic recession. Consumers rationally plan their budget, increase the number of purchases made in discount stores or buy own-label goods in order to maintain their old level of consumption with a decreasing income. In addition, they seek information on cheaper products and sales promotions, purchase goods online, prepare for shopping and avoid compulsive behaviours. This trend is also popular among wealthier and better educated consumers.

7. Prosumption is a form of innovative consumption that requires intelligence and creativity from the consumer. It combines consumption and production for own use, which in the case of energy consumers is also associated with energy production using renewable sources. The consumer becomes a producer and an entrepreneur, which sets him/her apart from other consumers and allows him/her to increase income or reduce costs related to the goods consumed (Śleszyńska-Świderska, 2017, p. 56). Prosumption fits perfectly into the new consumption trend referred to as 
hyperpersonalization, which uses an entire range of IT tools and business activity transfers to personalize the market offer, tailored to individual consumer preferences (Hajduk and Zalega, 2013).

8. Other trends, for example virtualization (satisfying consumer needs via the Internet), cocooning (moving public life home and consumption without leaving home), ethnocentrism (preference for domestic products).

\section{The subject, methodology and performance of the analysis}

The subject of the analysis was a data set containing information collected in the survey conducted among individual customers of two energy suppliers: Estabanell Energia (Spain) and SEnerCon (Germany). The prime goal of the survey was to identify the respondents' attitude to energy saving. Therefore the questionnaire included questions that mainly concerned:

- behaviour and actions that the respondents already take to reduce their energy consumption,

- areas of their current energy consumption (e.g. heating, cooking, entertainment),

- actions that they declare to implement in their households to reduce energy consumption in the future.

These questions were aimed to build the characteristics of respondents as energy consumers and determine how consciously they approached the problem of rational energy consumption. The responses were also used to identify the types of consumer behaviour, mainly in terms of the attitude to energy saving. In addition, the questionnaire included questions characterizing a respondent's household concerning, for example, the number of people in a household, the dominant age group, income, education, current employment status (demographics).

The survey was conducted among 151 respondents, but due to the requirements of the statistical method applied - principal component analysis - all observations that lacked responses were removed. As a result, the data set covered 124 complete responses. In addition, each question was represented by one variable and the responses, which were encoded numerically, created the values of the variables ${ }^{3}$. Due to the assumptions of the statistical methods used, only the variables whose values could be presented on the ordinal scale were used in the analysis ${ }^{4}$.

The empirical part used selected multivariate statistical methods for analysis, while the survey was conducted in two stages.

${ }^{3}$ Possible responses to the questions concerning activities aimed at energy saving now and in the future: 'always' (1), 'often' (2), 'occasionally' (3), 'rarely' (4), 'never' (5). The questions about activities declared for the future gave the following choice of responses: 'already done' (1), 'very possible in the near future' (2), 'not possible in the near future' (3), 'never / I do not know' (4).

${ }^{4}$ Principal component analysis assumes that a survey uses metric variables. The authors chose ordinal variables because it is possible to upgrade the ordinal scale to the quotient scale by reformulating the responses in the questionnaire. 


\subsection{The method of the identification of the factors related to energy consumption and saving}

The first stage of the study applied principal component analysis in order to identify the factors representing relevant aspects of energy consumption by indicating possible areas of energy saving and reduced energy consumption.

Principal component analysis is a method that involves the transformation of primary variables into mutually unorthogonal new variables, the so-called principal components, which are a linear combination of original variables. PCA enables the examination of mutual relationships in a set of variables and identifies the initial variables that have a significant impact on the components. This impact is represented by factor loadings, which can be interpreted as coefficients of correlation between the original variables and the components that were created. Principal component analysis is also seen as a method used for identifying hidden variables (i.e. components), which are not directly observable and which can contribute to the explanation of the relationships and connections in the examined data set.

PCA is a popular method, extensively described in Polish and world literature. It is discussed in detail by a variety of researchers, for example (Kim and Mueller, 1978a, 1978b; Sztemberg-Lewandowska and Zacny, 2004]; Sztemberg-Lewandowska, 2009). Due to the applied character of the article, it only presents the general idea behind this method, which will allow for the easier interpretation of the results.

\subsection{Analysis of the impact of demographic and economic factors on the principal components representing the aspects of energy consumption and saving}

The second stage of the analysis involved the application of the Kruskal-Wallis test in order to check which selected demographic and economic factors (i.e. age, education, income, and current employment status) significantly affect a given type of energy consumer behaviour related primarily to reduced energy consumption.

The Kruskal-Wallis test (Kruskal, 1952; Kruskal and Wallis, 1952) is the nonparametric equivalent of analysis of variance, which allows to conduct tests when the restrictive assumptions of the classic version of analysis are not fulfilled. This is a rank test for comparing the distributions of a variable in subgroups designated by levels of the factor examined. The absence of significant differences for the analysed variable in the indicated subgroups ${ }^{5}$ means that the factor constituting these subgroups has no significant impact on the variable.

\footnotetext{
${ }^{5}$ The absence of significant differences in the average values of the examined variable is verified using the hypothesis o frank equality for this variable in the selected subgroups (see Kruskal, 1952). In the article, the hypothesis of the absence of a relationship was verified at the level of significance 0.05 in each case.
} 


\section{The results of the analysis}

The principal component analysis that was conducted as part of the study identified 12 new features, which together account for $72 \%$ of the variability of the original variables. These 12 components can be interpreted as the basic types of energy consumer behaviour focused on rational and sustainable energy consumption. What differentiates them is the type of dominant activity, its nature and degree of complexity, as well as the determinants affecting decisions related to energy consumption.

In addition to identifying basic, homogeneous groups of consumer behaviour, the study also aimed to determine to what extent factors such as the dominant age group of household members, income, education and employment status affect energy consumer behaviour.

Table 1 presents the factor loadings obtained as a result of principal component analysis ${ }^{6}$. As mentioned above, the factor loading is identified with the coefficient of the correlation between the original variable and the component. This means that the higher the absolute value of the factor loading, the greater the impact a given variable has on the component. Accordingly, we can say that the loadings with high absolute values (marked bold in Table 1) indicate the variables that play the largest part in the interpretation of a given component.

The first component can be interpreted as energy saving behaviour mostly associated with responsible and sustainable water consumption in the household. These can involve choices that reduce the consumption of hot water when taking a shower or bath, using the kettle to boil only the amount of water that will be used immediately, or washing clothes at a low temperature. Such behaviour does not require specialist knowledge, only ecological awareness and the adoption of pro-environmental values and attitudes. Therefore the respondents declared behaviour classified in this group as one they had initiated and already performed on a regular basis ('always' was indicated by $42-49 \%$ respondents, while 'already done' was indicated by $47-$ $88 \%$ ) or as the ones they intended to introduce in their household in the future. In addition, the examination of the impact of selected factors on consumer behaviour showed that one of the demographic factors exerted a significant influence on the group. The respondents declaring the age of 41-64 as dominant in their household were more likely to manifest the behaviour indicated in this group. The first group is therefore characterized by the ecological approach to energy consumption combining sustainable energy use with economic motivation to economize on household costs.

The second component is the most strongly correlated with energy saving through behaviour oriented towards broadly understood energy efficiency. They comprise both simple actions, such as changing the lighting system in use (bulbs) to the ecological and energy saving one, and investment initiatives that, for example, require the consumer to replace household appliances with a higher energy efficiency class. Also in this

${ }^{6}$ With Varimax rotation, which enabled the easier interpretation of the principal components. 


\begin{tabular}{|c|c|c|c|c|c|c|c|c|c|c|c|c|c|c|}
\hline$\simeq$ & $\Xi$ & $\begin{array}{l}0 \\
\stackrel{0}{0}\end{array}$ & $\stackrel{\overbrace{}}{0}$ & $\begin{array}{l}\infty \\
\stackrel{0}{0} \\
0\end{array}$ & $\begin{array}{l}\text { m. } \\
0\end{array}$ & तु & 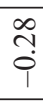 & ?ै? & $\begin{array}{l}\infty \\
\stackrel{0}{0}\end{array}$ & $\stackrel{2}{2}$ & i̊ & $\begin{array}{l}\infty \\
\text { ते } \\
\text { in }\end{array}$ & $\begin{array}{l}\stackrel{0}{0} \\
\end{array}$ & $\stackrel{0}{\circ}$ \\
\hline$=$ & $\underline{m}$ & $\begin{array}{l}5 \\
0 \\
0\end{array}$ & $\begin{array}{l}t \\
\dot{0}\end{array}$ & $\stackrel{\text { ô }}{\dot{\varphi}}$ & $\stackrel{m}{0}$ & $\stackrel{=}{0}$ & $\frac{7}{9}$ & तึ & $\begin{array}{l}1 \\
\dot{q}\end{array}$ & oे & $\stackrel{8}{0}$ & $\begin{array}{l}\infty \\
0 \\
0\end{array}$ & $\stackrel{8}{8}$ & $\begin{array}{l}\stackrel{0}{0} \\
\end{array}$ \\
\hline ㅇ & $\simeq$ & $\begin{array}{l}\stackrel{\circ}{\circ} \\
\end{array}$ & $\stackrel{\mathcal{I}}{O}$ & $\begin{array}{l}\text { D. } \\
\stackrel{0}{0}\end{array}$ & $\begin{array}{l}\infty \\
\stackrel{0}{0} \\
\end{array}$ & $\overbrace{0}^{m}$ & $\stackrel{0}{0}$ & $\begin{array}{l}\overrightarrow{0} \\
\dot{0}\end{array}$ & $\stackrel{8}{\circ}$ & $\begin{array}{l}\text { D. } \\
\stackrel{0}{0}\end{array}$ & $\begin{array}{l}\overline{1} \\
\stackrel{1}{1}\end{array}$ & 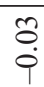 & $\begin{array}{l} \pm \\
\end{array}$ & $\vec{\square}$ \\
\hline$a$ & $=$ & $\stackrel{?}{\circ}$ & $\stackrel{\circ}{\circ}$ & ó. & $\stackrel{0}{\stackrel{0}{\varphi}}$ & $\stackrel{0}{0}$ & $\underset{0}{\tilde{O}}$ & $\begin{array}{l} \pm \\
\end{array}$ & $\stackrel{n}{0}$ & $\stackrel{0}{0}$ & $\begin{array}{l} \pm \\
0\end{array}$ & $\frac{\infty}{0}$ & $\begin{array}{l}\stackrel{0}{0} \\
\dot{0}\end{array}$ & $\begin{array}{l}\circ \\
0\end{array}$ \\
\hline$\infty$ & $\stackrel{0}{ }$ & $\stackrel{\text { กิ }}{0}$ & $\stackrel{\widetilde{\jmath}}{\circ}$ & $\begin{array}{l}\stackrel{0}{0} \\
:\end{array}$ & $\stackrel{0}{\circ}$ & $\stackrel{\Xi}{\circ}$ & $\overrightarrow{\widetilde{p}}$ & $\begin{array}{c}0 \\
? \\
? \\
1\end{array}$ & $\begin{array}{l}\tilde{O} \\
\stackrel{0}{0}\end{array}$ & $\stackrel{\text { ô }}{\varphi}$ & $\begin{array}{l}\text { İ } \\
\text { d }\end{array}$ & $\begin{array}{l}\text { ते } \\
0\end{array}$ & $\stackrel{\Xi}{\circ}$ & to \\
\hline
\end{tabular}

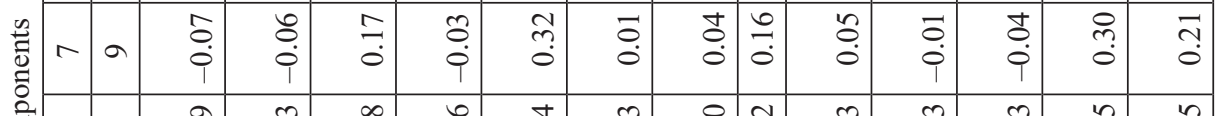

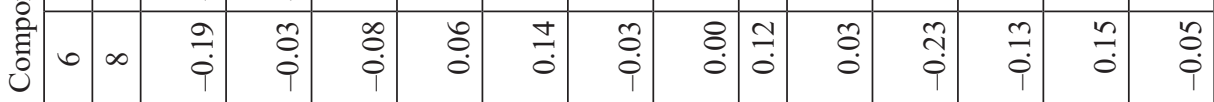

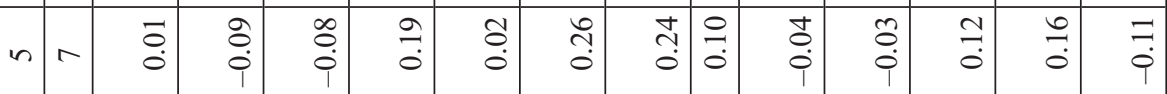

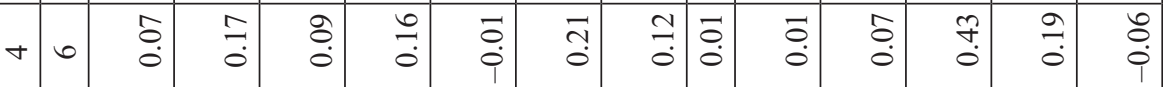

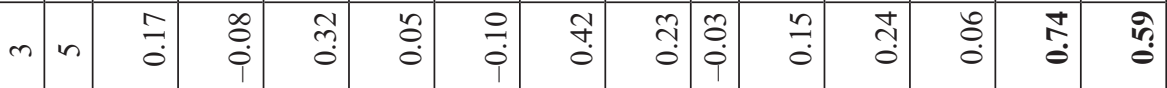

\begin{tabular}{|c|c|c|c|c|c|c|c|c|c|c|c|c|c|c|}
\hline \multirow[b]{2}{*}{-} & $\nabla$ & $\stackrel{8}{\circ}$ & $\begin{array}{l}0 \\
0 \\
0\end{array}$ & $\stackrel{\overrightarrow{0}}{0}$ & ָे & $\stackrel{\infty}{0}$ & $\stackrel{7}{\circ}$ & $\stackrel{2}{\circ}$ & $\begin{array}{l}\stackrel{\circ}{\circ} \\
\stackrel{0}{\circ}\end{array}$ & $\stackrel{ \pm}{\stackrel{\infty}{0}}$ & 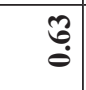 & $\stackrel{t}{\text { th }}$ & $\stackrel{m}{0}$ & $\frac{n}{0}$ \\
\hline & $m$ & $\stackrel{\infty}{\stackrel{\infty}{0}}$ & $\stackrel{\mathbb{S}}{\mathscr{S}}$ & $\stackrel{\mathbb{S}}{\stackrel{0}{0}}$ & \begin{tabular}{l}
$\tilde{b}$ \\
\hdashline
\end{tabular} & مٌ & 每 & గ్రి & $\stackrel{0}{0}$ & $\stackrel{n}{0}$ & $\stackrel{0}{\stackrel{0}{0}}$ & ठ̊. & $\stackrel{\circ}{\frac{0}{0}}$ & \\
\hline 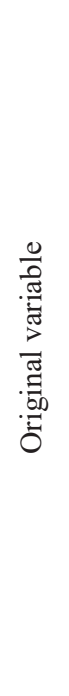 & $N$ & 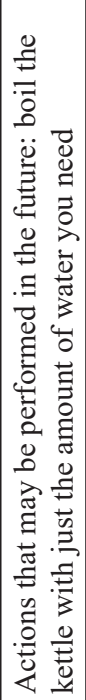 & 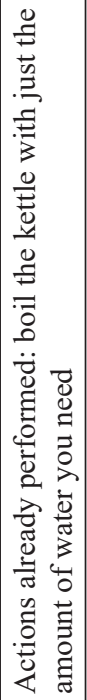 & 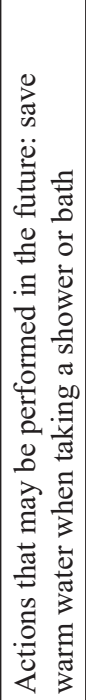 & 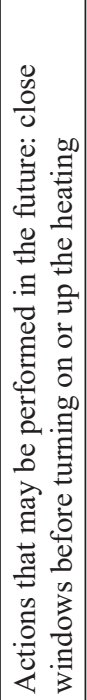 & 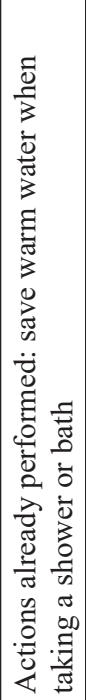 & 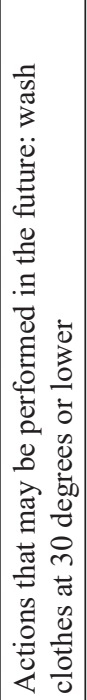 & 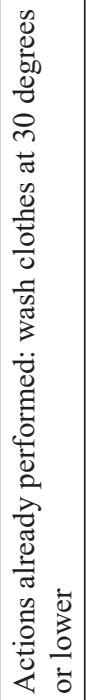 & 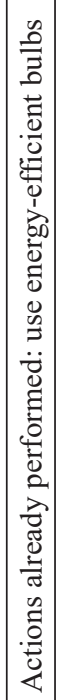 & 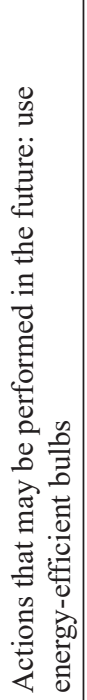 & 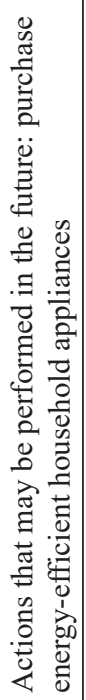 & 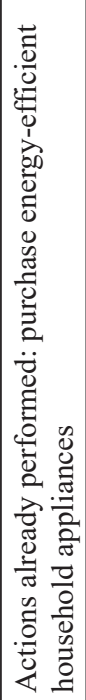 & 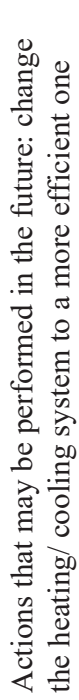 & 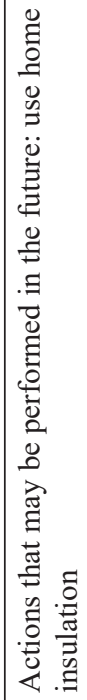 \\
\hline$z^{0}$ & - & & & & & & & & & & & & & \\
\hline
\end{tabular}




\begin{tabular}{|c|c|c|c|c|c|c|c|c|c|c|c|c|}
\hline $\begin{array}{l}\hat{o} \\
\dot{9}\end{array}$ & $\stackrel{+}{0}$ & $\begin{array}{l}0 \\
\stackrel{0}{0}\end{array}$ & $\frac{0}{0}$ & $\frac{m}{9}$ & $\stackrel{+}{0}$ & 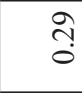 & $\begin{array}{l}\circ \\
\stackrel{0}{0}\end{array}$ & $\begin{array}{l}\hat{0} \\
\dot{\varphi}\end{array}$ & $\stackrel{n}{\circ}$ & $\stackrel{n}{0}$ & ô. & $\stackrel{\infty}{c}$ \\
\hline$\stackrel{\overbrace{}}{\tilde{0}}$ & $\begin{array}{l}\infty \\
\text { n? } \\
\varphi^{p}\end{array}$ & $\begin{array}{l}\widetilde{O} \\
\stackrel{0}{0}\end{array}$ & $\stackrel{n}{\circ}$ & $\begin{array}{l}\text { Oे } \\
\stackrel{0}{0}\end{array}$ & $\frac{9}{0}$ & $\stackrel{-}{0}$ & $\begin{array}{l}8 \\
\stackrel{0}{0}\end{array}$ & $\begin{array}{l}\overrightarrow{0} \\
\dot{0}\end{array}$ & $\stackrel{\Xi}{\stackrel{\Xi}{0}}$ & $\begin{array}{l}\text { ¿ } \\
\dot{0}\end{array}$ & $\stackrel{0}{\circ}$ & $\bar{c}$ \\
\hline$\vec{ָ}$ & $\stackrel{\infty}{n}$ & $\begin{array}{l}\dot{\Xi} \\
\stackrel{0}{0}\end{array}$ & $\stackrel{\circ}{\circ}$ & 웅 & ọ & $\stackrel{8}{8}$ & $\stackrel{8}{8}$ & $\begin{array}{l}\stackrel{\partial}{0} \\
\dot{\varphi}\end{array}$ & $\stackrel{ \pm}{\dot{0}}$ & 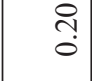 & $\frac{1}{0}$ & \\
\hline ֻి & $\begin{array}{l}\text { ¿ } \\
\dot{0}\end{array}$ & $\ddot{0}$ & $\stackrel{\infty}{\circ}$ & $\frac{N}{0}$ & $\stackrel{8}{\circ}$ & $\tilde{0}$ & $\stackrel{n}{\circ}$ & $\stackrel{\Xi}{0}$ & $\frac{1}{0}$ & $\frac{0}{0}$ & $\hat{0}$ & $\frac{0}{c}$ \\
\hline $\begin{array}{l}\widetilde{O} \\
\stackrel{0}{0}\end{array}$ & $\frac{a}{0}$ & $\stackrel{\infty}{\circ}$ & $\begin{array}{l}\overrightarrow{0} \\
\dot{0}\end{array}$ & $\exists$ & $\stackrel{\infty}{\circ}$ & กे & ㅇ. & $\stackrel{ \pm}{0}$ & $\stackrel{8}{8}$ & $\hat{0}$ & $\begin{array}{l}n \\
\hat{1}\end{array}$ & $\stackrel{J}{J}$ \\
\hline$\stackrel{n}{9}$ & $\stackrel{\circ}{\circ}$ & $\frac{m}{0}$ & $\stackrel{\infty}{\stackrel{\infty}{0}}$ & $\stackrel{0}{\stackrel{0}{0}}$ & $\exists$ & $\stackrel{\infty}{\circ} \stackrel{0}{0}$ & ö. & $\begin{array}{l}8 \\
\stackrel{0}{0}\end{array}$ & $\stackrel{m}{\circ}$ & ñ. & 范 & ñ \\
\hline$=$ & $\begin{array}{l}0 \\
\stackrel{0}{0}\end{array}$ & ō & $\begin{array}{l}\text { oे } \\
\text { + }\end{array}$ & 웅 & $\stackrel{\circ}{\circ}$ & ָ̃ & $\hat{\sigma}$ & ڤ̊ & $\stackrel{8}{8}$ & $\frac{n}{0}$ & $\stackrel{8}{0}$ & $\stackrel{\infty}{\varrho}$ \\
\hline $\begin{array}{l}\infty \\
\stackrel{0}{0} \\
\stackrel{9}{0}\end{array}$ & $\stackrel{0}{0}$ & $\begin{array}{l}\text { Oे } \\
\stackrel{0}{0}\end{array}$ & $\begin{array}{l}\dot{0} \\
\dot{9}\end{array}$ & $\stackrel{\infty}{\oplus}$ & $\stackrel{\infty}{\circ}$ & 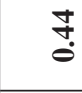 & $\begin{array}{l}\dot{J} \\
\dot{0}\end{array}$ & $\stackrel{2}{0}$ & $\stackrel{0}{\circ}$ & $\stackrel{\widetilde{N}}{0}$ & $\frac{0}{\dot{9}}$ & $\stackrel{\infty}{\infty}$ \\
\hline$\tilde{n}$ & $\frac{ \pm}{\dot{\varphi}}$ & $\stackrel{\substack{\infty \\
\hdashline}}{ }$ & $\stackrel{\infty}{\infty}$ & $\begin{array}{l}n \\
0 \\
0\end{array}$ & $\stackrel{\widetilde{o}}{\stackrel{0}{0}}$ & $\frac{m}{\dot{0}}$ & $\begin{array}{l}0 \\
\stackrel{0}{0}\end{array}$ & $\begin{array}{l}n \\
\stackrel{0}{0}\end{array}$ & $\frac{ \pm}{0}$ & ֻे & $\stackrel{8}{\circ}$ & $\frac{n}{c}$ \\
\hline חֶ? & חֶֶ: & $\stackrel{\overrightarrow{0}}{\dot{\varphi}}$ & $\frac{\infty}{0}$ & $\frac{0}{\stackrel{0}{9}}$ & $\frac{9}{0}$ & Oे. & $\begin{array}{l}n \\
0 \\
0\end{array}$ & $\stackrel{m}{\circ}$ & $\stackrel{+}{\dot{0}}$ & $\stackrel{\sim}{\tilde{\sigma}}$ & $\overrightarrow{0}$ & กิ \\
\hline$\stackrel{\text { Oे }}{0}$ & $\frac{\infty}{0}$ & $\stackrel{1}{0}$ & $\stackrel{0}{0}$ & $\begin{array}{l}0 \\
0\end{array}$ & $\begin{array}{l}\dot{\Xi} \\
\dot{0}\end{array}$ & $\frac{\infty}{0}$ & $\begin{array}{l}\check{O} \\
\stackrel{0}{0}\end{array}$ & 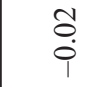 & Oे. & ָֻ & $\stackrel{+}{0}$ & $\frac{n}{c}$ \\
\hline$\stackrel{1}{\circ}$ & $\stackrel{m}{\circ}$ & $\frac{m}{0}$ & 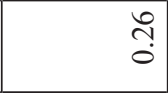 & $\frac{m}{9}$ & $\overline{0}$ & 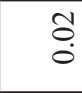 & $\begin{array}{l}\text { O̦ } \\
\stackrel{\varphi}{0}\end{array}$ & $\begin{array}{l}0 \\
\stackrel{0}{0} \\
0\end{array}$ & $\stackrel{\overbrace{}}{\tilde{\sigma}}$ & $\begin{array}{l}\circ \\
\stackrel{0}{0}\end{array}$ & $\frac{ \pm}{0}$ & č \\
\hline 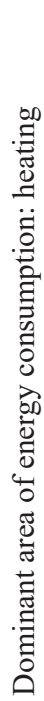 & 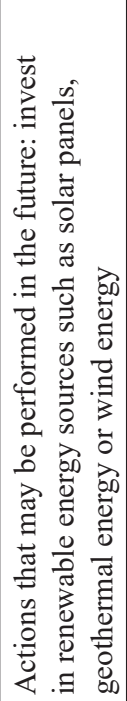 & 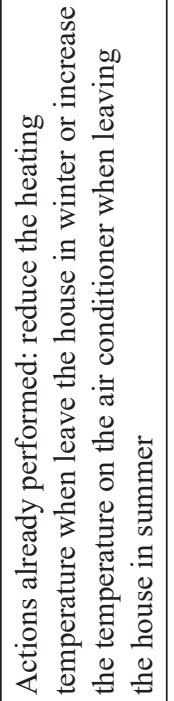 & 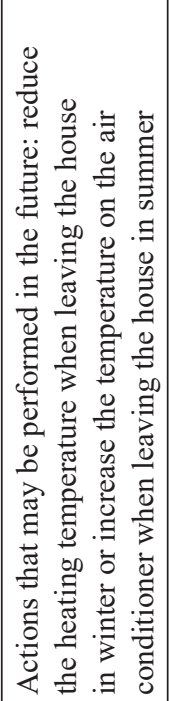 & 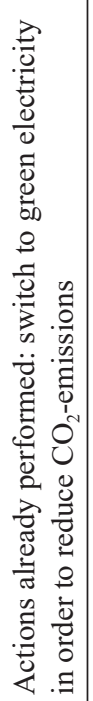 & 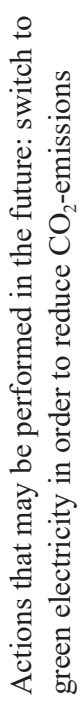 & 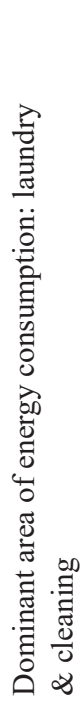 & 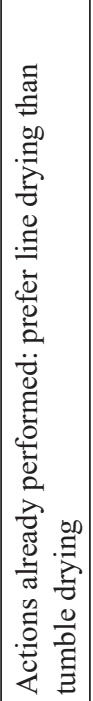 & 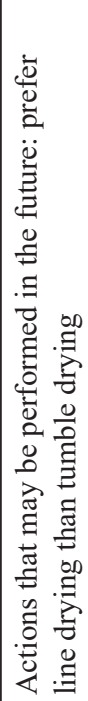 & 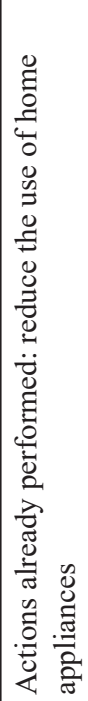 & 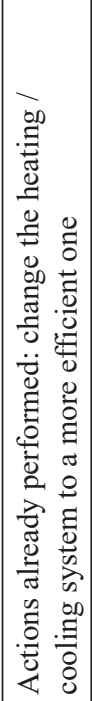 & 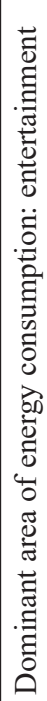 & 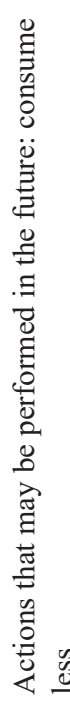 \\
\hline & & \multicolumn{2}{|l|}{$\nabla$} & \multicolumn{3}{|c|}{$n$} & & \multicolumn{4}{|c|}{$r$} \\
\hline
\end{tabular}




\begin{tabular}{|c|c|c|c|c|c|c|c|c|c|c|c|}
\hline \pm & ڤo. & $\stackrel{n}{\tilde{c}}$ & $\begin{array}{l}n \\
\stackrel{1}{0}\end{array}$ & $\stackrel{\circ}{\circ}$ & $\stackrel{0}{\stackrel{0}{9}}$ & $\begin{array}{l}\text { ¿ } \\
\dot{0}\end{array}$ & $\frac{1}{0}$ & $\stackrel{8}{\circ}$ & $\stackrel{\sim}{\stackrel{2}{0}}$ & $\stackrel{0}{\stackrel{0}{0}}$ & 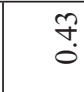 \\
\hline$\underline{-}$ & $\begin{array}{l}\infty \\
0 \\
0 \\
\end{array}$ & $\overrightarrow{7}$ & $\begin{array}{l}\stackrel{0}{0} \\
\dot{0}\end{array}$ & $\frac{1}{0}$ & ठิ & $\stackrel{\text { กิ }}{0}$ & @) & $\stackrel{\hat{\imath}}{\dot{\theta}}$ & 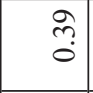 & $\begin{array}{l}\overline{0} \\
0\end{array}$ & $\stackrel{\widehat{\vartheta}}{0}$ \\
\hline$\simeq$ & ơ & $\frac{1}{0}$ & $\begin{array}{l}\overrightarrow{0} \\
\dot{0}\end{array}$ & $\begin{array}{l}0 \\
0 \\
\dot{0}\end{array}$ & $\stackrel{m}{\stackrel{\theta}{9}}$ & $\stackrel{m}{\stackrel{9}{+}}$ & $\begin{array}{l}\stackrel{o}{+} \\
\stackrel{0}{0}\end{array}$ & $\stackrel{n}{2}$ & ஸे & $\frac{0}{9}$ & $\stackrel{\infty}{\circ}$ \\
\hline$=$ & ö & $\stackrel{\sim}{\tilde{c}}$ & $\stackrel{\infty}{\oplus}$ & $\begin{array}{l}\hat{\sigma} \\
\dot{\theta}\end{array}$ & $\stackrel{\text { ô }}{0}$ & $\stackrel{\sigma}{0}$ & $\begin{array}{l}\infty \\
0 \\
0 \\
\end{array}$ & $\frac{m}{0}$ & $\stackrel{0}{0}$ & $\stackrel{\circ}{\circ}$ & $\frac{m}{9}$ \\
\hline 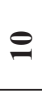 & $\stackrel{\hat{\theta}}{\hat{\theta}}$ & $\stackrel{1}{6}$ & $\stackrel{\infty}{\circ}$ & 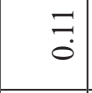 & $\frac{m}{0}$ & $\overrightarrow{\dot{\sigma}}$ & \begin{tabular}{l}
$\infty$ \\
\multirow{1}{*}{} \\
0
\end{tabular} & $\begin{array}{l}\hat{0} \\
0\end{array}$ & $\stackrel{+}{m}$ & $\begin{array}{l}\mathscr{0} \\
0 \\
0\end{array}$ & $\frac{ \pm}{\dot{9}}$ \\
\hline$a$ & $\stackrel{\text { oे }}{\circ}$ & $\stackrel{\circ}{\circ}$ & $\grave{ָ}$ & $\frac{5}{0}$ & $\frac{1}{9}$ & $\frac{\sim}{0}$ & $\hat{n}$ & $\begin{array}{l}\dot{\Xi} \\
\stackrel{0}{0}\end{array}$ & $\stackrel{\overrightarrow{0}}{0}$ & $\begin{array}{l}\text { ¿ } \\
\stackrel{0}{0}\end{array}$ & ö. \\
\hline$\infty$ & $\hat{0}$ & 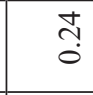 & $\stackrel{n}{\circ}$ & $\frac{m}{0}$ & $\begin{array}{l}\text { J } \\
\stackrel{0}{0}\end{array}$ & $\frac{n}{0}$ & $\vec{a}$ & $\begin{array}{l}0 \\
0 \\
0 \\
\end{array}$ & $\stackrel{0}{\stackrel{0}{0}}$ & $\frac{n}{9}$ & $\stackrel{\overbrace{}}{0}$ \\
\hline r & 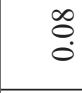 & $\begin{array}{l}n \\
0\end{array}$ & $\frac{\sim}{\stackrel{0}{0}}$ & $\begin{array}{l}0 \\
0 \\
0\end{array}$ & $\exists$ & $\stackrel{m}{?}$ & $\begin{array}{l}n \\
0 \\
0 \\
0\end{array}$ & $\stackrel{\infty}{\circ}$ & $\stackrel{+}{m}$ & $\frac{0}{\stackrel{0}{0}}$ & กै \\
\hline 0 & $\frac{\mathfrak{T}}{\stackrel{0}{0}}$ & $\stackrel{8}{8}$ & $\frac{\sim}{\stackrel{0}{0}}$ & $\begin{array}{l}\tilde{o} \\
\stackrel{0}{ }\end{array}$ & Ő & $\begin{array}{l}8 \\
0\end{array}$ & $\begin{array}{l}+ \\
\tilde{\varphi} \\
0\end{array}$ & $\stackrel{n}{\circ}$ & $\stackrel{n}{0}$ & $\stackrel{\infty}{\circ}$ & $\frac{9}{0}$ \\
\hline$n$ & $\begin{array}{l}0 \\
0 \\
0\end{array}$ & $\stackrel{\text { ণิ }}{\text { ஸे }}$ & $\begin{array}{l}8 \\
\dot{0}\end{array}$ & $\underset{\dot{\sigma}}{\vec{J}}$ & $\stackrel{n}{\circ}$ & $\stackrel{8}{\stackrel{8}{0}}$ & $\begin{array}{l}\dot{a} \\
\dot{0}\end{array}$ & $\begin{array}{l}\dot{O} \\
\stackrel{0}{0}\end{array}$ & ֻ̊ & $\frac{0}{0}$ & त̂ \\
\hline$\nabla$ & $\stackrel{m}{\ddot{0}}$ & $\stackrel{+}{0}$ & $\frac{1}{0}$ & $\stackrel{0}{\stackrel{0}{0}}$ & $\stackrel{5}{0}$ & $\frac{\infty}{0}$ & $\frac{n}{0}$ & $\stackrel{n}{\circ}$ & $\frac{\infty}{0}$ & $\stackrel{0}{0}$ & $\tilde{ָ}$ \\
\hline$m$ & O̊. & $\frac{1}{0}$ & $\stackrel{\infty}{\circ}$ & $\frac{m}{0}$ & $\begin{array}{l}\hat{0} \\
\dot{9}\end{array}$ & $\frac{2}{0}$ & $=$ & $\begin{array}{l}\text { O̦ } \\
\stackrel{+}{+}\end{array}$ & ָָ & ¿্. & $\underset{\nabla}{\vec{f}}$ \\
\hline$N$ & 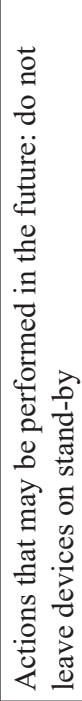 & 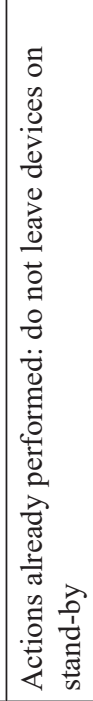 & 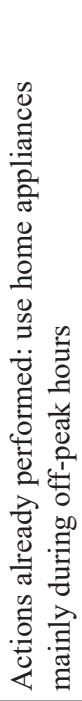 & 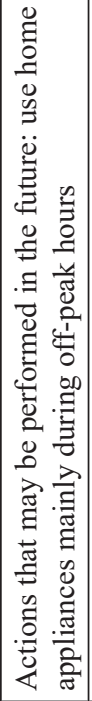 & 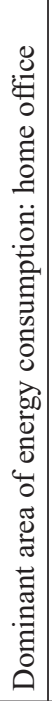 & 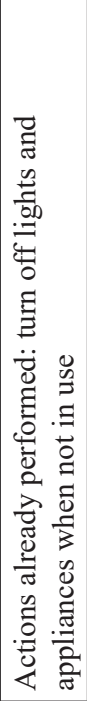 & 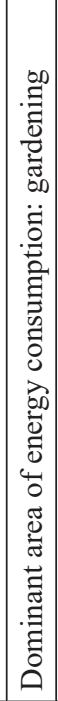 & 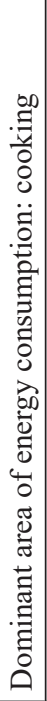 & 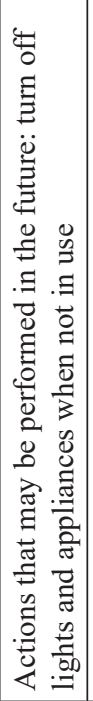 & 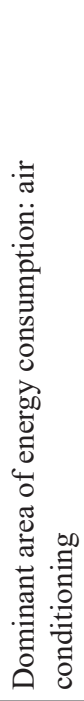 & 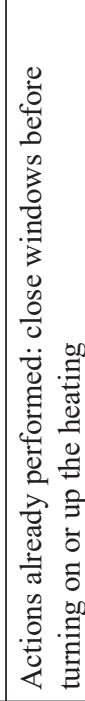 \\
\hline- & \multicolumn{2}{|c|}{$\infty$} & \multicolumn{2}{|c|}{$a$} & \multicolumn{3}{|c|}{ 으 } & \multicolumn{2}{|r|}{$\Xi$} & \multicolumn{2}{|c|}{$\simeq$} \\
\hline
\end{tabular}


case, the respondents declared that they had already done it (52-60\%), always did it (43-44\%), often did it (41-43\%) or considered making such decisions in the near future (36-42\%). Although in this group no links with the factors determining energy consumption were observed, it can be concluded that consumers declaring such behaviour tend to choose responsible and sustainable consumption while maintaining their current lifestyle or improving its quality. Such behaviour can also be included in the smart shopping trend, where the consumer plans purchases with prudence, does not act in a compulsive way, and seeks reliable information.

The third component embraces behaviour related to changing the way a house or apartment is heated. This group also includes investment actions in the area of thermal insulation and renewable energy sources introduced into the energy consumption structure of the household. This type of behaviour is a manifestation of the sustainable and responsible consumption trend and the so-called prosumerism, which means that the energy consumer is, at the same time, the energy producer. According to Bywalec and Rudnicki (2002, p. 146), factors stimulating prosumerism are, for example, the increased amount of free time and the need to spend it in an attractive way; the opportunity to perform work at home; changes in education, especially lifelong learning; changes in work organization and the re-evaluation of the role of work in human life, as well as the evolution of work towards creativity. These observations are confirmed by the survey which showed that households with a dominant age group of 41-64, retired or self-employed, are more inclined to save energy in this way. However, there are also respondents who declare that they do not consider such actions at all or that they do not find them applicable in their household (8-20\%).

The fourth component can be characterized as choices made in order to save energy while household members are out or away. Such actions mainly involve the reduction in heating in winter or the limited use of air conditioning in summer. Approximately $75 \%$ of respondents indicated these kinds of behaviour as the most common in their household. According to the Kruskal-Wallis test, however, this behaviour is significantly affected by the type of work. Therefore, full-time employees are more likely to adopt such attitudes and actions than energy consumers declaring other forms of employment. Consumer behaviour depends on the type of a need and the knowledge about how to satisfy this need. Consumers declaring energy saving actions in this group can control and manage their energy needs. This is often related to them being better educated, which embraces the development of a specific set of consumer values and needs and the concretization of needs in particular market conditions, including controlled expenditure.

Energy saving actions grouped in the fifth component are also associated with a good education and high ecological awareness. Consumers declare that in order to reduce energy consumption they want to use or already use "green" energy. In addition, their goal is not only to save energy, but also to reduce the negative impact on the environment by lowering $\mathrm{CO}_{2}$ emissions. The analysis of relationships showed that such an attitude corresponds most strongly with households where people aged 18-25 
are not in the majority. Consequently, it can be assumed that pro-ecological behaviour characteristic of mature consumers, who are more aware of their needs. Income also plays a significant role, since such choices often require substantial investment. Although the analysis did not identify income as a factor affecting such behaviour, it can be inferred implicitly from the distribution of responses, which is significantly different from the other groups, that income may be the reason why some respondents declared that such solutions were not applicable in their household (11-31\%) or they did not yet know whether such solutions were possible in their case (9-24\%).

The next three components $(6,7,8)$ are related to the activities that fall within the trend involving reduced energy consumption, i.e. deconsumption. This goal can be achieved either with the simplest changes in consumer behaviour (component 6), where instead of using energy consuming devices in everyday life, respondents choose natural solutions, for example line drying, or, as in the case of the $8^{\text {th }}$ component, they pay attention even to the smallest waste of energy and try to prevent it, for example unplugging unused household appliances. The Kruskal-Wallis test showed that actions aimed at even the smallest energy savings in households work best where there are no children and where the dominant group does not include people aged 26-40. Finally, the 7 th component comprises modes of behaviours that intend to significantly reduce the volume of energy consumed by limiting the use of household appliances. The respondents who display this attitude also want to change the heating or air-conditioning system to a more efficient one, or simply consume less energy in every aspect of everyday life. Interestingly, types of behaviour included in this group are negatively correlated with energy consumption for recreational purposes, which may imply that consumers declaring this attitude pursue a healthy and frugal lifestyle. It can be assumed that they spend their free time outdoors, do sports or meet friends, preferring an active lifestyle, which allows saving energy without lowering the comfort of living.

The last component (9), which can be interpreted conclusively, is related to actions aimed at the deliberate choice of energy rates and household energy consumption in off-peak periods, when energy prices are lower. This requires that the consumer has knowledge of the particulars of energy rates, is conversant with the market and has the option to amend the terms of the contract with the energy supplier. Therefore it comes as no surprise that also in this case the distribution of responses is significantly different from the other groups. The majority of responses indicated that consumers did not apply these solutions or that the solutions did not concern them. Moreover, only $42 \%$ of respondents declared that it was possible for them to use appliances in such a way in the near future.

Principal component analysis identified three more components, but due to the inconclusive values of the factor loadings it is difficult to interpret the results and link the actions to specific choices aimed at energy saving. It can only be said that the $10^{\text {th }}$ component identifies the actions that are characteristic of work at home, the $11^{\text {th }}$ component comprises activities related to energy saving during cooking and preparing meals for household members, while the $12^{\text {th }}$ component is mainly associated with 
air conditioning. Surprisingly, the Kruskal-Wallis test showed that actions to save energy during cooking are related to the income factor to a significant extent. It is the only component in the whole analysis that strongly depends on income. Moreover, post-hoc tests performed to supplement the Kruskal-Wallis test, showed that highestincome households stand out in this respect and their members, while cooking, save the least energy.

\section{Conclusion}

In contemporary consumption, including energy consumption, a variety of interesting changes are underway. They are mainly caused by the dynamic growth of economies, globalization and the integration of markets, evolving lifestyles and social trends, as well as the growing awareness of societies faced with ecological crises. Therefore, the challenge that has emerged is to achieve a sustainable, optimal level of energy consumption, i.e. one that is sufficient to satisfy basic needs and, at the same time, ensure that the consumption of natural resources will decline and the harmful impact of energy on the environment will be reduced without affecting the right of the next generations to such consumption. At present, energy consumers are becoming increasingly interested in smart consumption, which involves ensuring the quality and purpose of consumption as well as its alignment with their values. Consumers cocreate goods and services and cooperate with businesses. They replace compulsive shopping with prudent decision making. While making purchase decisions, they only buy the products they really need, paying attention to their quality, because in this way they can extend their useful life though recycling or changing the intended use, which reduces waste (Milczarek, 2015). It can be argued that consumers have learned sustainable and smart consumption, shifting from the welfare economy focused on maximized possession to the economy of moderation, or "just in time" possession (Leitschuh-Fecht and Lorek, 1999, pp. 4-5). These trends can also be observed among the respondents, so the main conclusions that can be derived from the analysis are as follows:

1. The respondents very rarely declare ignorance of the types of actions that they could take in the future in order to save energy.

2. The majority of responses indicate that behavioural actions dominate over investment behaviour, which means that even actions that reduce energy consumption to a small extent are recognized as meaningful by consumers.

3. Based on the responses, it can be concluded that in general, the respondents act as conscious consumers, educated in the issues related to ecology, environment and energy consumption. They are also aware of the need to reduce energy consumption and use a number of solutions in their everyday life in order to achieve this. The general knowledge leading to rational energy consumption is in no way related to the respondents' education, since it transpired that education has no significant impact on energy-saving behaviour and attitudes. 
4. With the exception of the group of behaviour characteristic of the $11^{\text {th }}$ component, the other groups of consumer attitudes and actions aimed at energy saving are not related to the income factor. However, it should be remembered that the study was conducted among German and Spanish consumers.

5. Similarly, the other factors under analysis, i.e. age group and current employment status, do not have a strong impact on the results. Only in a few individual cases the Kruskal-Wallis test showed a significant relationship between certain aspects of energy saving and the factors characterizing the respondent or his/ her household.

6. Finally, it can be concluded that the components representing consumer behaviour groups are homogeneous in terms of energy saving actions.

\section{Bibliography}

Bednarz, J. (2017). Prosumpcja jako rezultat zmian zachodzących w zachowaniach konsumentów na przykładzie przemysłu spożywczego. Studia Oeconomica Posnaniensia, 5(1), 7-24. DOI: $10.18559 /$ SOEP.2017.1.1

Bywalec, C., and Rudnicki, L. (2002). Konsumpcja. Warszawa: PWE.

Hajduk, M. T., and Zalega, T. (2013). Zachowania prosumpcyjne polskich konsumentów na rynku produktów żywnościowych, Zarządzanie Innowacyjne w Gospodarce i Biznesie, 2(17).

https://repozytorium.uwb.edu.pl/jspui/bitstream/11320/6767/1/A_Sleszynska-Swiderska_ Zachowania_polskich_konsumentow.pdf(19.08.2019)

Kim, J. O., and Mueller, C. W. (1978a). Factor Analysis. Statistical Methods and Practical Issues. Beverly Hills: Sage.

Kim, J. O., and Mueller, C. W. (1978b). Introduction to Factor Analysis. What it is and how to do it. Beverly Hills: Sage.

Kruskal, W. (1952). A nonparametric test for the several sample problem. Annals of Mathematical Statistics, (23), 525-540.

Kruskal, W., and Wallis, W. (1952). Use of ranks in one-criterion variance analysis. Journal of the American Statistical Association, (47), 583-621.

Leitschuh-Fecht, H., and Lorek, S. (Eds.) (1999). Privater Konsum und Nachhaltige Entwicklung, Bonn: Positionspapier des Forum Umwelt \& Entwicklung, Positionspapier zur Vorlage bei der CSD 7.

Milczarek, A. (2015). Wybrane aspekty zachowań konsumentów w kontekście zrównoważonej konsumpcji. Studia $i$ prace Wydziału Nauk Ekonomicznych $i$ Zarzadzania Uniwersytetu Szczecińskiego, 40(2), 131-143. DOI: 10.18276/sip.2015.40/2-10

Sobczyk, G. (2014). Współczesna konsumpcja - nowe trendy na polskim rynku. Zeszyty Naukowe WSEI, seria: Ekonomia, 9(2), 87-104.

Sztemberg-Lewandowska, M. (2009). Analiza czynnikowa. In: M. Walesiak, E. Gatnar (Eds.), Statystyczna analiza danych z wykorzystaniem programu R (318-353). Warszawa: Wydawnictwo Naukowe PWN.

Sztemberg-Lewandowska, M., and Zacny, B. (2004). Analiza czynnikowa. In: E. Gatnar, M. Walesiak (Eds.), Metody statystycznej analizy wielowymiarowej w badaniach marketingowych (186-245). Wrocław: Wydawnictwo Akademii Ekonomicznej we Wrocławiu.

Śleszyńska-Świderska, A. (2017). Zachowania polskich konsumentów w warunkach globalnego kryzysu gospodarczego. Rozprawa doktorska. Retrieved from

Woś, J., Rochacka, J., and Kasperek-Hoppe, M. (2004). Zachowania konsumentów - teoria i praktyka. Poznań: Wydawnictwo Akademii Ekonomicznej w Poznaniu. 